Provided for non-commercial research and education use. Not for reproduction, distribution or commercial use.

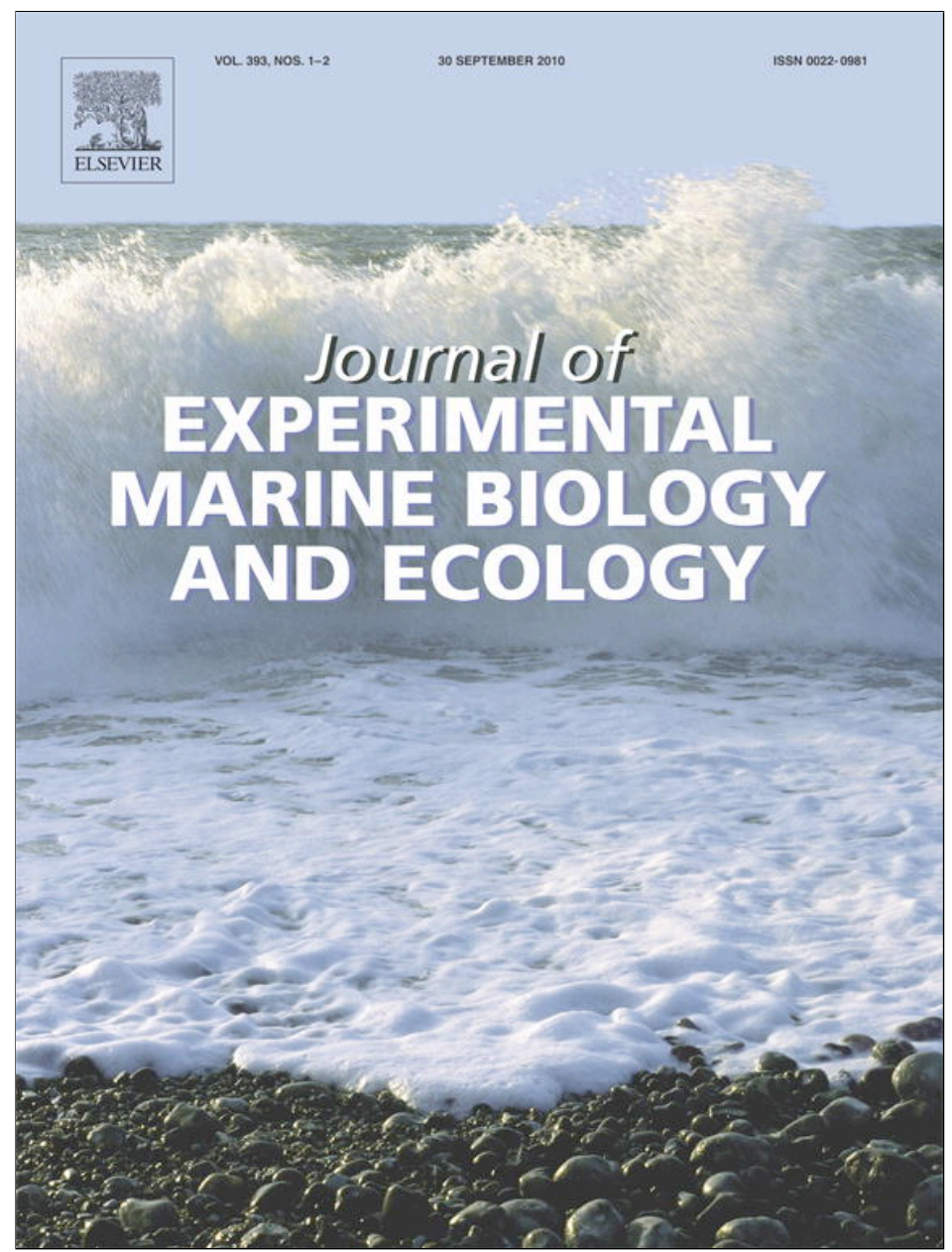

This article appeared in a journal published by Elsevier. The attached copy is furnished to the author for internal non-commercial research and education use, including for instruction at the authors institution and sharing with colleagues.

Other uses, including reproduction and distribution, or selling or licensing copies, or posting to personal, institutional or third party websites are prohibited.

In most cases authors are permitted to post their version of the article (e.g. in Word or Tex form) to their personal website or institutional repository. Authors requiring further information regarding Elsevier's archiving and manuscript policies are encouraged to visit:

http://www.elsevier.com/copyright 


\title{
Comparison of heat-shock responses between the hydrothermal vent shrimp Rimicaris exoculata and the related coastal shrimp Palaemonetes varians
}

\author{
Delphine Cottin ${ }^{\mathrm{a}}$, Bruce Shillito ${ }^{\mathrm{a}}$, Thomas Chertemps ${ }^{\mathrm{b}}$, Sven Thatje ${ }^{\mathrm{c}}$, Nelly Léger ${ }^{\mathrm{a}}$, Juliette Ravaux ${ }^{\mathrm{a}, *}$ \\ ${ }^{a}$ Université Pierre et Marie Curie-Paris 06 (UPMC), UMR 7138, Equipe Adaptations aux Milieux Extrêmes, 7 Quai Saint-Bernard, 75005 Paris, France \\ b UPMC UMR-A 1272, Physiologie de l'Insecte: Signalisation et Communication, 7 Quai Saint-Bernard, 75005 Paris, France \\ ${ }^{c}$ National Oceanography Centre, Southampton, School of Ocean and Earth Science, University of Southampton, European Way, Southampton SO14 3ZH, UK
}

\section{A R T I C L E I N F O}

\section{Article history:}

Received 12 October 2009

Received in revised form 7 June 2010

Accepted 8 June 2010

\section{Keywords:}

Heat stress

HSP70

Hydrothermal vents

Real-time PCR

Shallow-water

Shrimp

\begin{abstract}
A B S T R A C T
The deep-sea vent shrimp Rimicaris exoculata is believed to occur at the hot end of the hydrothermal biotope in order to provide essential elements to its epibiosis. Because it is found close to hot venting water, R. exoculata lives in a highly fluctuating environment where temperature $\left(2-40{ }^{\circ} \mathrm{C}\right.$ in the swarms $)$ can exceed its critical maximal temperature $\left(33-38.5 \pm 2{ }^{\circ} \mathrm{C}\right)$. In order to understand how this vent shrimp copes with hyperthermia, we compared its molecular heat stress response following an acute but non-lethal heat-shock $\left(1 \mathrm{~h}\right.$ at $30^{\circ} \mathrm{C}$ ) with that of its monophyletic shallow-water relative, the shrimp Palaemonetes varians, known to frequently undergo prolonged exposure at temperatures up to $30{ }^{\circ} \mathrm{C}$ in its natural environment during summer. We isolated four isoforms of heat-shock proteins 70 (HSP70) in $R$. exoculata ( 2 constitutive and 2 inducible isoforms) and two isoforms in P. varians ( 1 constitutive and 1 inducible isoform) and quantitatively compared their magnitude of induction at mRNA level, using real-time PCR, in the case of experimentally heat-stressed shrimps, with respect to control (unstressed) animals. Here, we report the first quantification of the expression of multiple $h s p 70$ genes following heat stress in a deep-sea vent species living at $2300 \mathrm{~m}$ depth. Our results show a strong increase of hsp70 inducible genes in the vent shrimp ( 400-fold) compared to the coastal shrimp ( 15 -fold). We therefore propose that, the highly inducible molecular response observed in $R$. exoculata may contribute to the ability of this species to tolerate thermal extremes.
\end{abstract}

(c) 2010 Elsevier B.V. All rights reserved.

\section{Introduction}

Hydrothermal vents are highly dynamic deep-sea environments characterized by great spatial and temporal heterogeneity. In fact, as a result of turbulent mixing between the hot hydrothermal fluid $\left(350{ }^{\circ} \mathrm{C}\right)$ and the cold ambient sea water $\left(2^{\circ} \mathrm{C}\right)$, species colonizing black smoker chimney walls may be subjected to rapid and severe changes of temperature in their environment (Tunnicliffe, 1991). To survive in this highly fluctuating thermal habitat, these vent species may have developed specific adaptations at behavioural and/or physiological levels (Childress and Fisher, 1992; Somero, 1992; Fisher, 1998).

The alvinocarid shrimp, Rimicaris exoculata (Williams and Rona, 1986 ) is one of the most abundant invertebrates (1000-3000 ind. $\mathrm{m}^{-2}$ ) at the Mid-Atlantic Ridge vent sites, forming dense swarms on the walls of active chimneys (Van Dover et al., 1988; Gebruk et al., 2000; Desbruyères et al., 2001). This species is believed to fulfil most of its nutritional needs by feeding from the abundant bacterial epibiosis hosted within its gill chambers, and may therefore be constrained to

\footnotetext{
* Corresponding author. Tel.: +331442735 02; fax: + 33144275250. E-mail address: juliette.ravaux@snv.jussieu.fr (J. Ravaux).
}

maintain close proximity to the hydrothermal fluid (Segonzac et al., 1993; Rieley et al., 1999; Zbinden et al., 2004). Indeed, the epibionts are believed to be chemoautotrophic sulphur-oxidizers, and mesophilic temperatures $\left(>20^{\circ} \mathrm{C}\right)$ have been suggested to be important for carbon fixation (Wirsen et al., 1993; Gebruk et al., 2000). Adaptation to elevated temperature may thus constitute a selective advantage for the exploitation of $\mathrm{H}_{2} \mathrm{~S}$ that is needed to support the chemolithoautotrophic metabolism of its symbiont (Somero, 1992). Discrete in situ temperature measurements ranging from 2 to $40^{\circ} \mathrm{C}$ have been reported within the swarms of $R$. exoculata and up to $70^{\circ} \mathrm{C}$ only several centimetres away from the swarms (Van Dover et al., 1988; Gebruk et al., 1993; Segonzac et al., 1993; Desbruyères et al., 2000, 2001; Schmidt et al., 2008). Gebruk et al. (2000) also reported that up to $30 \%$ of collected specimens were damaged (scalded cuticle) by heat exposure. However, recent in vivo experiments revealed that $R$. exoculata does not tolerate sustained exposures to temperatures in the $33-38.5 \pm 2{ }^{\circ} \mathrm{C}$ range (Ravaux et al., 2003; Shillito et al., 2006). The adaptation strategy with respect to hyperthermia remains therefore to be explored in this vent shrimp.

To understand the underlying mechanisms through which high thermal tolerance is conferred to deep-sea vent fauna, it is important to know how their biological processes differ from their shallow-water relatives (Somero, 1992; Childress and Fisher, 1992; Mestre et al., 2009). In this study, we propose to compare the molecular heat stress response 
of the vent shrimp R. exoculata to a sustained exposure at a temperature close to its upper thermal limit $\left(30^{\circ} \mathrm{C}\right)$, with that of the coastal salt marsh shrimp Palaemonetes varians (Leach, 1814), which is known to frequently undergo such severe heat stress in its natural environment. This comparison is particularly relevant since $P$. varians also lives in a fluctuating thermal habitat (Healy, 1997) where the reported temperature minima $\left(0-2{ }^{\circ} \mathrm{C}\right)$ and maxima $\left(30-33^{\circ} \mathrm{C}\right)$ are comparable with those suggested to be encountered by the vent shrimp in its habitat (Lofts, 1956; Jefferies, 1964). Moreover, a study has recently shown, within the Caridea infraorder, a monophyletic relationship between palaemonid and alvinocarid shrimps (Tokuda et al., 2006).

We focused our investigations on a well-known family of stress biomarkers, the HSP70, since an immunodetection has already revealed an induction of these proteins in $R$. exoculata following a brief exposure at $25{ }^{\circ} \mathrm{C}$ (Ravaux et al., 2003). HSP70 proteins are known to function as chaperones, assisting in protein folding in response to a wide variety of stressors (Feder and Hofmann, 1999; Sørensen et al., 2003; Mayer and Bukau, 2005). They are among the most prominent proteins induced by heat and their role in conferring increased heat tolerance has been well established (Sanders, 1993; Parsell and Lindquist, 1993; Feder and Hofmann, 1999). In the HSP70 multigenic family, some members are expressed at extremely low level under normal conditions and increase significantly in response to stressors (stress-inducible proteins, HSP70) whereas others (cognate stress proteins, HSC70) are constitutively expressed under normal conditions but may be up-regulated under stress conditions (Lindquist and Craig, 1988; Feder and Hofmann, 1999). Presently, few data are available on HSP70 for vent species (Ravaux et al., 2003, 2007; Pruski and Dixon, 2007; Leignel et al., 2007; Cottin et al., 2008) and to our knowledge, only two studies deal with HSP70 gene regulation (Boutet et al., 2009; Ravaux et al., 2009).

Our investigations were initiated by Ravaux et al. (2007) who provided the first HSP70 sequences of hydrothermal vent species, one of which ( $h s p 70$ form 1 ) belonging to $R$. exoculata. We here characterized 3 additional cDNA belonging to the HSP70 family (two $h s c 70$ and one hsp70) in R. exoculata and the first HSP70 sequences (one $h s c 70$ and one $h s p 70$ ) in P. varians, and we propose to quantitatively compare their magnitude of induction at mRNA level, using real-time PCR, in the case of experimentally heat-stressed shrimps, with respect to control (unstressed) animals.

\section{Materials and methods}

\subsection{Animal collection}

Rimicaris exoculata specimens were collected during the cruise "Momardream» (R/V Pourquoi pas?, Nautile submersible, July 2007) along the Mid-Atlantic ridge at the Rainbow vent site $\left(36^{\circ} 14^{\prime} \mathrm{N}, 33^{\circ} 54^{\prime}\right.$ $\mathrm{W}, 2300 \mathrm{~m}$ depth). Animals were sampled with a suction device operated by the submersible's hydraulic arm, and stored inside insulated Perspex cylinders until further transfer to the ship. Most of the shrimps survived the collection trauma, and live adult specimens ( 4 to $6 \mathrm{~cm}$ in length) were immediately re-pressurized inside the pressure vessel IPOCAMP for in vivo experiments (For details see Ravaux et al., 2003 and Cottin et al., 2008). Less than $2 \mathrm{~h}$ passed between the time the samples began decompression (submersible ascent) and the moment they were re-pressurized.

Adult specimens of $P$. varians ( 4 to $5 \mathrm{~cm}$ in length) were randomly caught with a fishnet from salt marsh ponds of the British coast near Lymington (Hampshire, England, $50^{\circ} 45^{\prime} \mathrm{N}, 1^{\circ} 32^{\prime} \mathrm{W}$ ) in November 2007. Freshly collected shrimps were then kept for 7 days at $10^{\circ} \mathrm{C}$, in $10 \mathrm{~L}$ PVC-tanks with filtered sea water (35 ppt salinity) under continuous aeration, and an artificial day-night cycle. During this acclimatization period, animals were fed with fish pellet, and half of the water was replaced every 2 days by fresh $10{ }^{\circ} \mathrm{C}$ filtered sea water.

\subsection{Heat-shock experiments}

2.2.1. Time course study of hsp70 in P. varians following a sudden heatshock

A time course study of $h s p 70$ expression levels was carried out on P. varians specimens following a sudden heat stress $\left(1 \mathrm{~h}\right.$ at $28^{\circ} \mathrm{C}$; Fig. $1 \mathrm{~A}$ ) in order to detect the time of the peak response. This experiment was performed using temperature-controlled seawater tanks (one tank set at $10^{\circ} \mathrm{C}$ and one tank set at $28^{\circ} \mathrm{C}$ ). Briefly, $10^{\circ} \mathrm{C}$ acclimatized shrimps (a total of 40 individuals) were suddenly transferred into a $28^{\circ} \mathrm{C}$-seawater tank with continuous aeration for $1 \mathrm{~h}$, and then put back at reference temperature $\left(10^{\circ} \mathrm{C}\right.$ tank). Ten individuals were then sampled and frozen $30 \mathrm{~min}, 2 \mathrm{~h}, 4 \mathrm{~h}$, and $6 \mathrm{~h}$ after the heat-shock, in order to measure their $h s p 70$ levels. Reference specimens (a total of 40 individuals) which had been maintained at $10{ }^{\circ} \mathrm{C}$ constant temperature were also sampled and frozen at each duration point (10 individuals per point).

\subsubsection{Ramp-shock experiments in P. varians and R. exoculata}

A ramp-shock experiment was carried out on $P$. varians and $R$. exoculata specimens. These experiments were performed inside the incubator IPOCAMP at in situ pressure for both species in order to obtain comparable heating rate (Fig. 1B). The experiment was carried out at atmospheric pressure on a total of 30 specimens for the coastal shrimp and at $23 \mathrm{MPa}$ on a total of 42 specimens for the hydrothermal vent shrimp, in flow-through mode $\left(20 \mathrm{l} \mathrm{h}^{-1}\right.$ flow rates). The temperature of the flowing seawater (filtered at $0.4 \mu \mathrm{m}$ ) is measured constantly in the inlet and outlet lines $\left( \pm 1^{\circ} \mathrm{C}\right)$. Animals were maintained $5 \mathrm{~h}$ at $10 \pm 1{ }^{\circ} \mathrm{C}$, then the water temperature was ramped to $28 \pm 2{ }^{\circ} \mathrm{C}$ (at a rate of $0.2^{\circ} \mathrm{C} / \mathrm{min}$ ) for P. varians and to $30 \pm 2{ }^{\circ} \mathrm{C}$ for $R$. exoculata (at a rate of $0.3^{\circ} \mathrm{C} / \mathrm{min}$ ). Shrimps were kept at this elevated water temperature for $1 \mathrm{~h}$, after which the temperature was

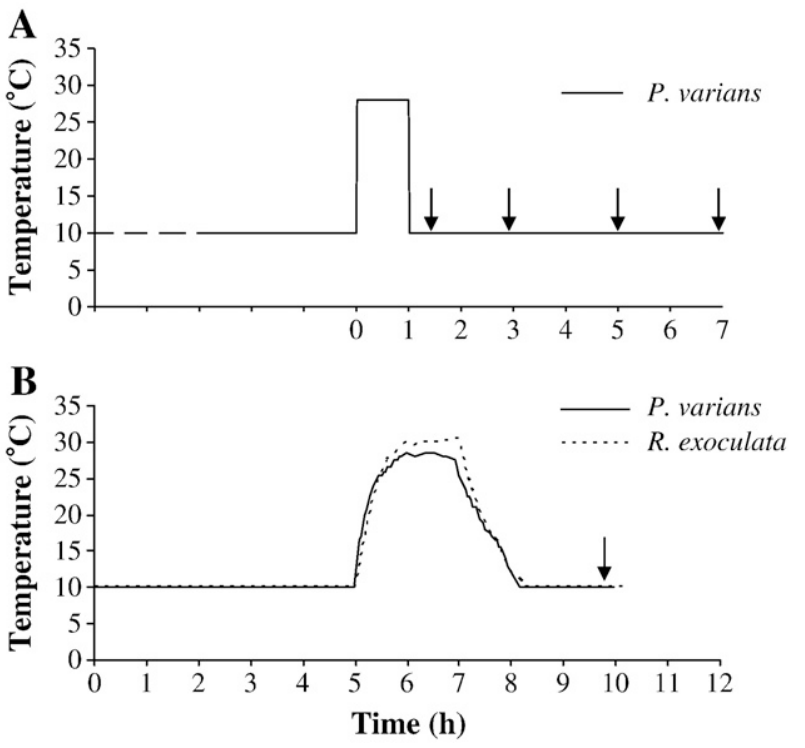

Fig. 1. (A) Temperature profile of the heat-shock experiment performed on P. varians shrimps using temperature-controlled water baths. $10{ }^{\circ} \mathrm{C}$-acclimatized shrimps were suddenly immersed in a $28{ }^{\circ} \mathrm{C}$-water bath for $1 \mathrm{~h}$ and then put back at $10^{\circ} \mathrm{C}$. Animals were then sampled $30 \mathrm{~min}, 2 \mathrm{~h}, 4 \mathrm{~h}$ and $6 \mathrm{~h}$ after the heat-shock (see black arrows) and rapidly frozen in liquid nitrogen. (B) Temperature profiles of heat-shock experiments performed on R. exoculata (broken line) and P. varians (solid line) specimens inside the pressurized IPOCAMP vessel. The animals were maintained for $5 \mathrm{~h}$ at $10^{\circ} \mathrm{C}\left( \pm 1{ }^{\circ} \mathrm{C}\right)$ and subsequently ramped to $28^{\circ} \mathrm{C}$ for $P$. varians and to $30^{\circ} \mathrm{C}$ for $R$. exoculata. After $1 \mathrm{~h}$ at this elevated temperature, the shrimps were given two hours recovery at $10^{\circ} \mathrm{C}$ (black arrow) and subsequently sampled and immediately frozen in liquid nitrogen for further molecular analysis. Temperature values $\left( \pm 2{ }^{\circ} \mathrm{C}\right.$ during heating events) correspond to the mean temperature obtained from $\mathrm{T} 1$ (upstream temperature of the water flow) and T2 (downstream temperature of the water flow) probes (see Ravaux et al., 2003 for more details). 
reduced to $10^{\circ} \mathrm{C}$, and maintained as such for 2 more hours, until the end of the experiment. It had previously been shown that a temperature of $30^{\circ} \mathrm{C}$ is non-lethal for $R$. exoculata specimens (Ravaux et al., 2003). In the case of $P$. varians, a preliminary heating experiment revealed a $40 \%$ mortality rate ( 12 dead animals on a total of 30 experimented shrimps) following a $1 \mathrm{~h}$ exposure at $35^{\circ} \mathrm{C}$ (data not shown). In view of this result, heating experiments on the coastal shrimp were finally carried out at lower temperature $\left(28 \pm 2{ }^{\circ} \mathrm{C}\right)$. At the end of the experiments, shrimps were rapidly dissected and frozen in liquid nitrogen for further analyses. Less than 10 min passed between the end of the experiments and the moment the last shrimp was frozen. Reference animals (48 specimens of $R$. exoculata and 31 specimens of $P$. varians) were maintained for the same duration as for the heating experiments (about $10 \mathrm{~h}$ ) at a constant temperature of $10{ }^{\circ} \mathrm{C}$.

\subsection{RNA extraction and reverse transcription}

Tissues from shrimp abdomens, with their cuticle, were ground in liquid nitrogen. The powder was homogenized in Trizol reagent (Invitrogen), and total RNA was isolated according to the manufacturer's instructions and quantified by spectrophotometry. RNA integrity was then evaluated by electrophoresis in a $1.2 \%$ agarose gel under denaturing conditions. Subsequently, single-stranded cDNA were synthesized from $3 \mu \mathrm{g}$ of shrimp abdomen total RNA using oligo $(\mathrm{dT})_{18}$-anchor primer and MMLV reverse transcriptase (200 units, Promega, Lyon, France). The reaction mixture contained dNTP mix

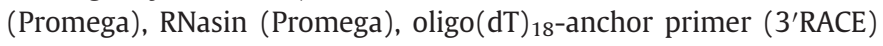
or a specific HSP70 primer ( $5^{\prime}$ RACE), sterile water and RNA template dissolved in a final volume of $25 \mu$. This solution was heated at $65^{\circ} \mathrm{C}$ for $5 \mathrm{~min}$ before addition of the enzyme and incubation for $1 \mathrm{~h}$ at $37^{\circ} \mathrm{C}$ and $15 \mathrm{~min}$ at $75^{\circ} \mathrm{C}$.

\subsection{CDNA amplification and rapid amplification of the $3^{\prime}$ and $5^{\prime} c D N A$} ends (RACE) for hsp70 in R. exoculata and P. varians

The cDNA encoding putative hsp70 genes in R. exoculata ( $h s p 70$ form 2 and $h s c 70$ form 3 ) and $P$. varians ( $h s p 70$ form 1 and $h s c 70$ form 2 ) were amplified by PCR amplification, using the degenerated primers HSP1, HSP2, HSP3 and HSP4 (Table 1). PCR amplifications were performed following a previously published protocol (Ravaux et al., 2007). The $5^{\prime}$ and $3^{\prime}$ ends of $R$. exoculata hsp70 cDNA were obtained using a SMART RACE cDNA amplification kit (Clontech, Mountain View, CA, USA) with univP and nested primers and the specific

Table 1

Nucleotide sequences of primers used in polymerase chain reaction for the amplification of reference genes and hsp70 sequences in Palaemonetes varians and Rimicaris exoculata.

\begin{tabular}{|c|c|c|}
\hline Primer & Direction & Sequences $\left(5^{\prime}-3^{\prime}\right)$ \\
\hline HSP1 & $\mathrm{F}$ & AAGGTGGARATCATCATCGCCAAYGAYCARGG \\
\hline HSP2 & $\mathrm{F}$ & TAYGTNGCVTTCACNGACAC \\
\hline HSP3 & $\mathrm{R}$ & AGGTTGTTGTCCTTGGTCATYGC \\
\hline HSP4 & $\mathrm{R}$ & TAGAARTCRATRCCYTCGAASAGACAGTC \\
\hline Rim8 & $\mathrm{F}$ & GCAACACCACCATCCCAACCAA \\
\hline Re4 & $\mathrm{R}$ & ATTGGCATCTATGTCAAAGGTC \\
\hline Rex2 & $\mathrm{F}$ & AAAGACCCATCCGAGAACAAGCGT \\
\hline Rex3 & $\mathrm{R}$ & AAGGTTTGGGTTTGCTTCGTGGGA \\
\hline Var3 & $\mathrm{F}$ & CTTGACGTGGCTCCTCTTTC \\
\hline Vari1 & $\mathrm{F}$ & CCTGGCGTGCTAATTCAAGT \\
\hline Vari3 & $\mathrm{F}$ & TGACGAGAAGCAGCGAGAGCGTA \\
\hline $5^{\prime}$ primer & $\mathrm{F}$ & ATGGCVAAGGCAMGYGCTGTSGGTAT \\
\hline 3' primer & $\mathrm{R}$ & TTASTCRACTTCTCRATGGTGGG \\
\hline UnivP & $\mathrm{F} / \mathrm{R}$ & $\begin{array}{l}\text { CTAATACGACTCACTATAGGGCAAGCAGTGGTATC } \\
\text { AACGCAGAGT }\end{array}$ \\
\hline Nested & $\mathrm{F} / \mathrm{R}$ & AAGCAGTGGTATCAACGCAGAGT \\
\hline \multicolumn{3}{|c|}{ Nucleotide codes: $R=A / G, Y=C / T, N=A / T / G / C, S=G / C . F$, forward; $R$, reverse } \\
\hline
\end{tabular}

primers Rim8 and Re4 for $h s p 70$ form2, and Rex2 and Rex3 for $h s c 70$ form3 (Table 1). The almost complete $P$. varians hsp70 cDNAs were obtained by performing nested PCR using nested specific primers (Var3 for hsp70 form1 and Vari1, Vari3 for hsc70 form2) and the 5' Primer or 3' Primer designed from multiple alignments of homologous sequences (Cottin et al., 2008). The PCR products were purified, subcloned, sequenced and identified as previously described (Ravaux et al., 2007). The resulting nucleotide sequences were then deposited in the GenBank database under the accession numbers FJ875280 ( hsp70 form2), FJ268954 (hsc70 form3) for R. exoculata and FJ356149 (hsp70 form1) and FJ875279 (hsc70 form2) for P. varians. A cDNA coding for a fourth isoform of HSP70 proteins was obtained for $R$. exoculata following a suppression subtractive hybridization procedure (using different stressors) performed in our lab but not described in this paper. This sequence, named hsc70 form 4 , was also deposited in GenBank under the accession number FJ654506.

\subsection{Sequence analysis}

A dataset of the available crustacean HSP70 nucleotide sequences was built from GenBank database, and was subsequently aligned with ClustalW. The ambiguously aligned regions were removed, leading to 1692 nucleotide positions. The sequences that proved too short to provide relevant information for tree-building purposes were removed (including $R$. exoculata hsp70 form 4), leading to a final dataset of 31 sequences that were rooted with the 3 branchiopods sequences from Artemia franciscana (GenBank accession no. AF427596), Daphnia magma (GenBank accession no. EU514494) and Moina macrocopa (GenBank accession no. EU514495). Phylogenetic relationships were then reconstructed by probabilistic methods, namely Maximum Likelihood (PHYML, Guindon and Gascuel, 2003) using the SYMIG model. Robustness of the topology was assessed by 100 bootstrap replicates.

2.6. Real-time PCR analysis of hsp70 in R. exoculata and P. varians shrimps

\subsubsection{DNAse treatment and reverse transcription}

Real-time PCR was used to accurately evaluate in both control and heat-shocked individuals the expression levels of the $h s p 70$ genes identified in $R$. exoculata and $P$. varians. For each individual, $4 \mu \mathrm{g}$ of total RNA was treated to remove DNA contamination by using the Turbo-DNAse kit (Ambion, Foster city, CA, USA) and then reversely transcribed to cDNA using the oligo $(\mathrm{dT})_{18}$ primer and the Superscript II reverse trancriptase kit (200 units, Invitrogen) according to the manufacturer's instructions. Amplification of hsp70 transcripts characterized in $R$. exoculata and $P$. varians was performed on cDNAs of single individual for control and heat-exposed shrimps ( $n=$ at least 3 individuals for each treatment). The specific primer pairs designed for the amplification of hsp70 transcripts in both species are shown in Table 2.

\subsubsection{Reference gene selection and primer design}

The expression of 4 (ß-actin, GAPDH, Rpl8 and 185 gene) and 3 reference genes ( $ß$-actin, GAPDH, $R$ pl8) were analysed for $R$. exoculata and $P$. varians, respectively. Based on crustacean genes in databases, degenerate primers were designed for GAPDH and Rpl8 genes using the Eprimer3 software (http://mobyle.pasteur.fr/cgi-bin/MobylePortal/ portal.py?form=eprimer3) considering conserved protein domains (Table 1). The resulted amplicons were then cloned using the TOPO TA cloning kit (Invitrogen) and sequenced (GATC Biotech, France). The corresponding sequences were deposited in GenBank (Rimicaris GAPDH FJ875278, Rimicaris Rpl8 FJ875277, Palaemonetes GADPH GQ120565, and Palaemonetes Rpl8 GQ120564). Subsequently, specific primers were designed and primer optimal annealing temperature was optimized using standard RT-PCR tests. For the $18 \mathrm{~S}$ and the ß-actin reference gene, 
Table 2

Primer sequences (F: forward; R: reverse) used for the real-time PCR analysis of Rimicaris exoculata and Palaemonetes varians genes.

\begin{tabular}{|c|c|c|}
\hline Primer & Direction & Sequences $\left(5^{\prime}-3^{\prime}\right)$ \\
\hline \multirow[t]{2}{*}{ Rimicaris hsp70 form 1} & $\mathrm{~F}$ & TAAGGACAATATGAAGCAGCAGC \\
\hline & $\mathrm{R}$ & AAATACAGAATGACAAAACACAG \\
\hline \multirow{2}{*}{ Rimicaris hsp70 form2 } & $\mathrm{F}$ & ACTGAAGAGGCTGGAAGGAAGC \\
\hline & $\mathrm{R}$ & GACGTAAGTGAATGAAGATGAAT \\
\hline \multirow[t]{2}{*}{ Rimicaris hsp70 form3 } & $\mathrm{F}$ & AAGGTTTGGGTTTGCTTCGTGGGA \\
\hline & $\mathrm{R}$ & TAGCGGGTGGCTCCACAAGGATT \\
\hline \multirow{2}{*}{ Rimicaris hsp70 form4 } & $\mathrm{F}$ & CAGAACAGGCTCACCCCAGAAG \\
\hline & $\mathrm{R}$ & GTTTGGCCCCCAACTTCTCCT \\
\hline \multirow[t]{2}{*}{ Palaemonetes hsp70 form1 } & $\mathrm{F}$ & CCAGCCGTCACCATCCAGGTGT \\
\hline & $\mathrm{R}$ & GCGGTCGATGTCCTCCTTGCTG \\
\hline \multirow[t]{2}{*}{ Palaemonetes hsp70 form2 } & $\mathrm{F}$ & TTCCTGAGGAGGATCGCAAA \\
\hline & $\mathrm{R}$ & CATTCCACCAGGAGGAGCAC \\
\hline \multirow{2}{*}{ Rimicaris GAPDH } & $\mathrm{F}$ & ССССTCATTGCTCTGGACTAC \\
\hline & $\mathrm{R}$ & ACCACCTTGGAAGTGAGCAGA \\
\hline \multirow[t]{2}{*}{ Rimicaris $18 \mathrm{~S}$} & $\mathrm{~F}$ & GCTGTGGATTGTAGGCCATGCGCCTAC \\
\hline & $\mathrm{R}$ & GGCTGCTGGCACCAGACTTGCCCTCCAA \\
\hline \multirow{2}{*}{ Rimicaris ß-actin } & $\mathrm{F}$ & ACCAGTGCTGAACGTGAGATCG \\
\hline & $\mathrm{R}$ & TCTCGTGGACACCAGCAGATTC \\
\hline \multirow[t]{2}{*}{ Rimicaris Rpl8 } & $\mathrm{F}$ & GAAGCTCCCATCAGGTGCCAAGAA \\
\hline & $\mathrm{R}$ & TTGTTACCACCACCGTGAGGATGC \\
\hline \multirow[t]{2}{*}{ Palaemonetes GAPDH } & $\mathrm{F}$ & AAGGGCGCCGAGGTTGTTGCTGTAA \\
\hline & $\mathrm{R}$ & GCACCAGCCTTGCTCCATGGAATGT \\
\hline \multirow[t]{2}{*}{ Palaemonetes ß-actin } & $\mathrm{F}$ & ACCAGTGCTGAACGTGAGATCG \\
\hline & $\mathrm{R}$ & TCTCGTGGACACCAGCAGATTC \\
\hline \multirow[t]{2}{*}{ Palaemonetes Rpl8 } & $\mathrm{F}$ & TCCCGGTCGTGGTGCACCTATT \\
\hline & $\mathrm{R}$ & GACGGCCTCGGTCACCAGTCTTT \\
\hline
\end{tabular}

specific primers were designed using sequences in GenBank (Rimicaris ß-actin FJ410324, Palaemonetes ß-actin FJ654525, Rimicaris 18S AM087652) (Table 2).

\subsubsection{Real-time quantitative $R T$-PCR}

All real-time quantitative RT-PCR reactions were performed on the LightCycler ${ }^{\circledR} 480$ Real-Time PCR Detection System (Roche, France). Each $12.5 \mu$ reaction consisted of $6.25 \mu$ LightCycler ${ }^{\circledR} 480$ Sybr Green I Master (Roche, France), $2.5 \mu \mathrm{l}$ diluted cDNA, $1.25 \mu \mathrm{l}$ of forward and reverse primer and $1.25 \mu \mathrm{l}$ of sterile water. PCR conditions were 1 cycle of $94{ }^{\circ} \mathrm{C}$ for $13.5 \mathrm{~min}$ followed by 45 cycles of $\left(94^{\circ} \mathrm{C} 30 \mathrm{~s}, 56^{\circ} \mathrm{C}\right.$ $30 \mathrm{~s}$, and $\left.72{ }^{\circ} \mathrm{C} 30 \mathrm{~s}\right)$ for $R$. exoculata cDNAs and 35 cycles of $\left(94^{\circ} \mathrm{C}\right.$ $30 \mathrm{~s}, 62{ }^{\circ} \mathrm{C} 30 \mathrm{~s}$, and $72{ }^{\circ} \mathrm{C} 30 \mathrm{~s}$ ) for P. varians cDNAs. After PCR, a melting curve analysis was performed in order to demonstrate the specificity of the PCR products. All primer pairs tested generated a single and discrete peak in the dissociation curve (data not shown). A negative control and a 5 -fold dilution series protocol of pooled cDNAs (from both control and hyperthermic treatments) were included in each run. The 5-fold dilution series were used to construct a relative standard curve to determine the PCR efficiencies and for further quantification analysis. In all experiments, all primer pairs gave amplification efficiencies of $90-100 \%$. Each reaction was run in triplicate (technical replicate).

\subsubsection{Determination of the best reference gene and data analysis}

Data were analysed with the LightCycler ${ }^{\circledR} 480$ software (Roche, France) and the crossing point values (Cp-values) were first determined for the reference genes. The average $C p$ value of each triplicate reaction was then used for subsequent analysis with the geNorm, Normfinder, and BestKeeper programs in order to determine the best reference gene. This approach relies on the principle that the expression of a perfect reference gene should be identical in all samples, independently of experimental conditions. For the comparison of control and heat-exposed individuals, the RPL8 gene was considered as displaying consistent expression in both $R$. exoculata and $P$. varians shrimps and therefore was determined to be the best reference gene for both species. Subsequently, the expression of $h s p 70$ genes was normalized to geometric means of this reference and the mean normalized gene expression of each triplicate reaction was then calculated with the Q-Gene software.

\subsection{Statistical analysis}

A Mann-Whitney Test was used to compare differences between heat-shocked and control samples for hsp70 genes in shrimps. All analyses were performed using STATISTICA version 7.0 (Statsoft) and significance levels were $p<0.05\left({ }^{*}\right)$.

\section{Results}

\subsection{Shrimp survival}

Most of the $R$. exoculata specimens originating from Rainbow (2300 $\mathrm{m}$ depth) appeared to withstand the decompression events during the collection process, except for some individuals which may have been damaged by the suction sampler. At $23 \mathrm{MPa}$, almost all animals were alive either after the reference experiment (92\% of survival after $10 \mathrm{~h}$ at $10^{\circ} \mathrm{C}$ ) or after the heat exposure ( $88 \%$ of survival after a $1 \mathrm{~h}$ exposure at $30^{\circ} \mathrm{C}, 10 \mathrm{~h}$ total duration).

No mortality was observed for $P$. varians specimens maintained at $10{ }^{\circ} \mathrm{C}$ either during the acclimatization period ( 7 days) in PVC-tanks or after the experiment performed inside IPOCAMP (10 h). Moreover, all the specimens were still alive and relatively active at the end of the heating experiments $\left(1 \mathrm{~h}\right.$ at $\left.28^{\circ} \mathrm{C}\right)$ even after $6 \mathrm{~h}$ of recovery.

\subsection{Description of shrimp HSP70 sequences}

One complete cDNA ( $h s c 70$ form3) and two partial cDNAs ( $h s p 70$ form 2 and $h s c 70$ form 4 ) were obtained for $R$. exoculata (see Fig. S1 in the Supplementary data files). The cDNA of R. exoculata hsp70 form 2 is 1978 nucleotides in length (601 amino acid), including a $1806 \mathrm{nt}$ coding region and a $3^{\prime}$ UTR of $172 \mathrm{nt}$ with a polyadenylation signal sequence (AATAAA at position 1935). The full-length cDNA of $R$. exoculata hsc70 form 3 is $2262 \mathrm{bp}$ in length with a single reading frame of $1965 \mathrm{nt}$ (654 amino acid) and a 273 nt-long 3' UTR, which contains the consensus polyadenylation signal at position 2222 . Finally, the partial cDNA hsc70 form4 is $428 \mathrm{nt}$ in length (142 amino acid).

Two partial cDNA were obtained for $P$. varians. The cDNA of $P$. varians hsp70 form 1 is a single reading frame of $1687 \mathrm{nt}$ (567 amino acid) and the cDNA of $P$. varians hsc70 form2 is a 1840 nt ORF (613 amino acid).

\subsection{Relationships among crustacean HSP70}

Two groups of sequences, which are supported by high bootstrap percentages values, are evidenced in the tree (Fig. 2). The first group, including $R$. exoculata form 3 and $P$. varians form 2 sequences (identified below as HSC70), would correspond to constitutively expressed $70 \mathrm{kDa}$ HSP, since nine of these sequences were clearly identified as HSC70. The second group, including $R$. exoculata form $1, R$. exoculata form 2 and $P$. varians form 1 sequences, would therefore correspond to heatinducible forms, since four of these sequences are identified as HSP70 (see below).

\subsection{Time course of hsp70 mRNA expression in P. varians}

A time course study of $h s p 70$ expression levels was performed in $P$. varians following a rapid transfer of the shrimps from $10^{\circ} \mathrm{C}$ to $28^{\circ} \mathrm{C}$. Fig. 3 represents the expression level of $h s p 70$ form 1 and $h s c 70$ form 2 for various time points of recovery: $30 \mathrm{~min}, 2 \mathrm{~h}, 4 \mathrm{~h}$ and $6 \mathrm{~h}$ after the $1 \mathrm{~h}$-heat-shock. The expression level of $h s p 70$ form 1 was higher in heat-shocked samples than in control samples at each time of recovery. This differential expression increased from 15 -fold at $30 \mathrm{~min}$ to 26 -fold at $2 \mathrm{~h}$ and to 54 -fold, $4 \mathrm{~h}$ after the heat-shock. 

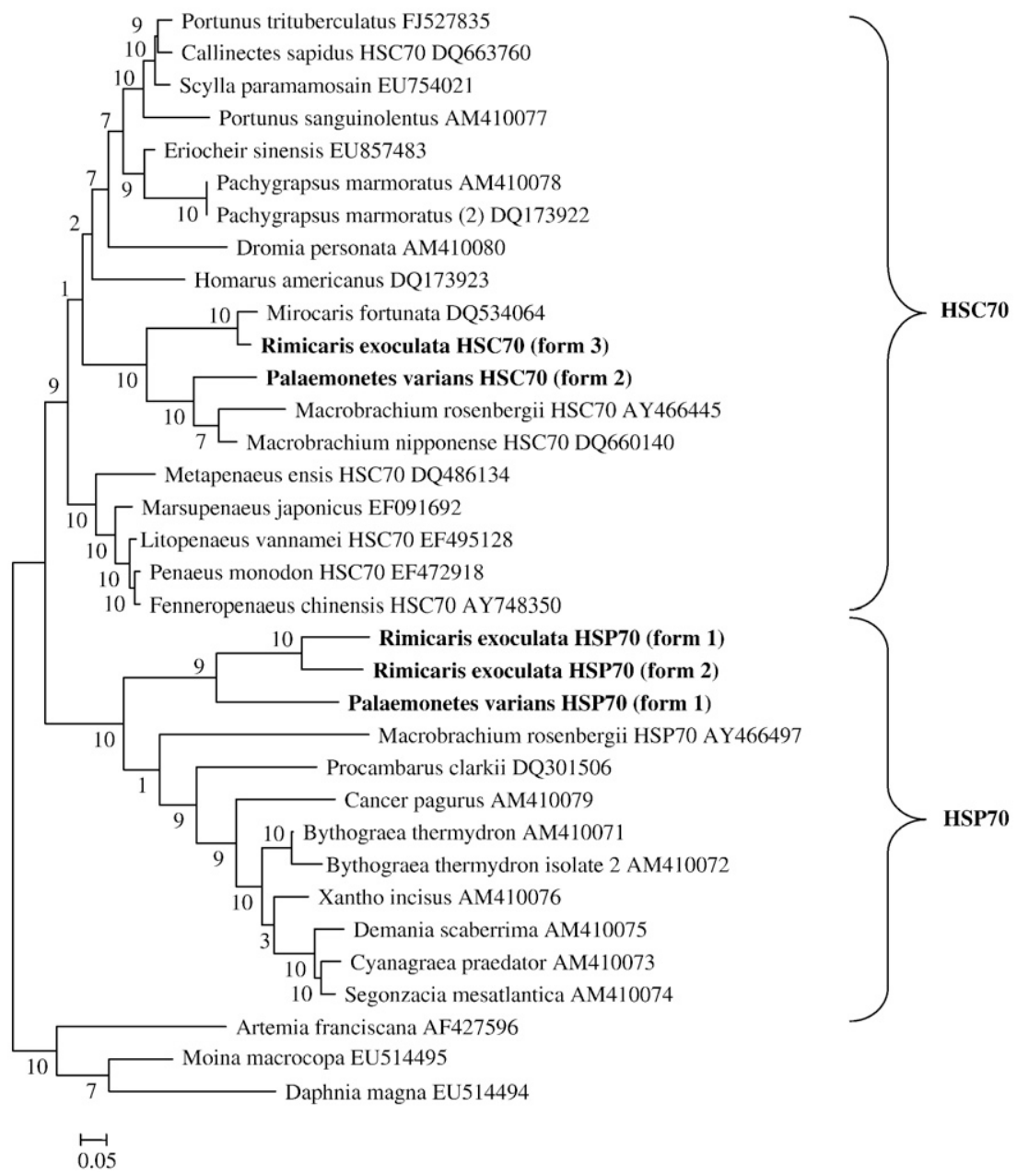

Fig. 2. Phylogenetic tree showing the relationships between the $h s p 70$ nucleotide sequences of decapod crustaceans. The $h s p 70$ sequences of 34 crustaceans were analysed through Maximum Likelihood (PHYML, Guindon and Gascuel, 2003) under a SYMIG model. The sequences that were clearly assigned to inducible forms (HSP70) or constitutive forms (HSC70) through expression analyses are annotated on the tree. The accession number of the nucleotide sequence is provided after each species name, and the sequences analysed in this paper are identified in bold. The values indicated on the branches correspond to bootstrap percentages (BP). According to this tree, there is a functional grouping of the sequences identified as HSP70 and HSC70.

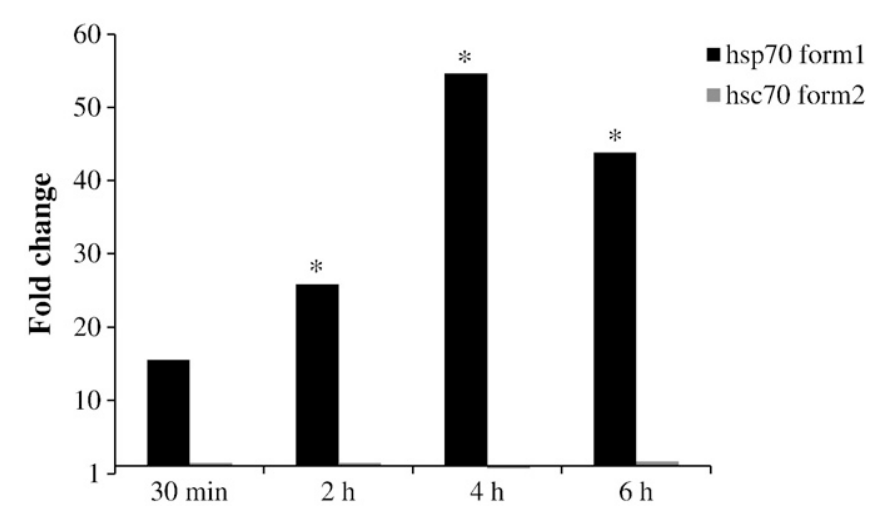

Fig. 3. Time course study of $h s p 70$ expression levels in Palaemonetes varians shrimps. The levels of $h s p 70$ form1 (black columns) and $h s c 70$ form2 (grey columns) were detected at different times of recovery following a sudden heat exposure at $28^{\circ} \mathrm{C}$ for $1 \mathrm{~h}$ (see Materials and methods). Expression level of $h s p 70$ were normalized to the corresponding RPL8 abundance and expressed as the ratio to control (constant temperature of $10^{\circ} \mathrm{C}$ ), considered as equal to 1 . All amplifications were reproduced in triplicate and values correspond to the mean normalized expression $( \pm$ SEM) of at least 3 independent samples ( $n=3$ or 4 individuals). To compare data, Mann-Whitney Test were used and the asterisk above the bars indicates a significant difference between the mean normal expression of control and heat-shocked samples $\left({ }^{*} p<0.05\right)$ of the same time point.
Finally, the expression of $h s p 70$ form 1 decreased to 43-fold, $6 \mathrm{~h}$ after stress. On the contrary, whatever the time point considered, no significant changes in hsc70 form 2 levels (1.4-fold at $30 \mathrm{~min}, 1.4$-fold at $2 \mathrm{~h}, 0.7$-fold at $4 \mathrm{~h}$ and 1.6 -fold at $6 \mathrm{~h}$ ) was observed between heatshocked and control samples.

\subsection{Expression analysis of hsp70 genes in R. exoculata and P. varians}

Using real-time PCR, changes in hsp70 expression levels were assessed in $R$. exoculata and $P$. varians specimens following the heatshock experiments performed inside IPOCAMP. Fig. 4A shows the expression levels obtained for $h s p 70$ form $1, h s p 70$ form $2, h s c 70$ form 3 and hsc70 form 4 in control $\left(10^{\circ} \mathrm{C}\right)$ and heat-shocked $R$. exoculata $\left(30^{\circ} \mathrm{C}\right)$. A significant difference between control and heat-shocked R. exoculata specimens was observed for $h s p 70$ form 1 and $h s p 70$ form 2 genes (Mann-Whitney Test, $p<0.05$ ), with a strong increase of expression levels after heat stress, reaching 373 -fold for $h s p 70$ form 1 and 132 -fold for $h s p 70$ form 2 . On the contrary, the expression levels of $h s c 70$ form3 (1.9-fold) and hsc70 form4 (0.7-fold) observed in heatshocked samples were not statistically different from those detected under control conditions, suggesting that these genes were not significantly affected by thermal stress.

The expression levels of the two hsp70 genes ( $h s p 70$ form 1 and hsc70 form2) identified in the coastal shrimp P. varians, for control $\left(10^{\circ} \mathrm{C}\right)$ and heat-exposed shrimps $\left(28^{\circ} \mathrm{C}\right)$, are shown in Fig. $4 \mathrm{~B}$. The 
A

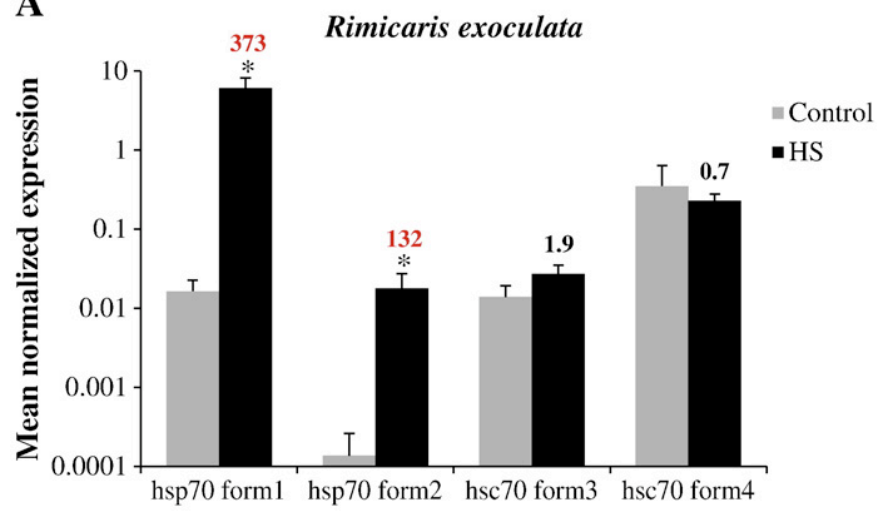

B

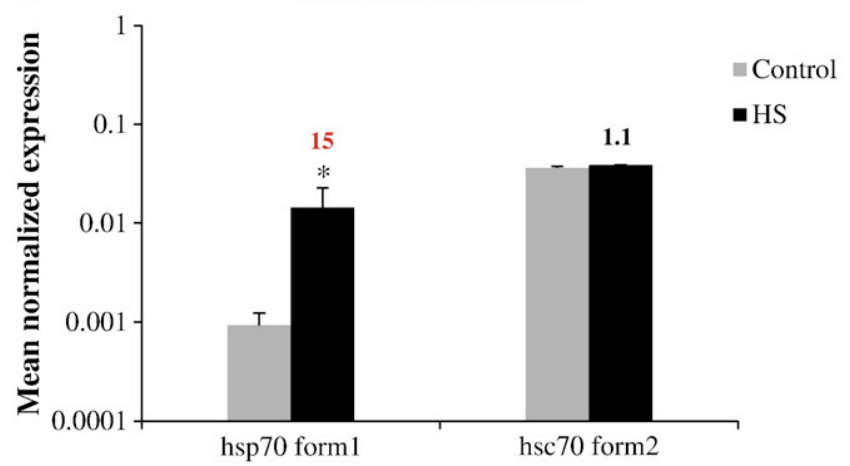

Fig. 4. Expression levels of $h s p 70$ genes obtained by $q P C R$ in $R$. exoculata (A) and P. varians (B) for control (grey columns; $10{ }^{\circ} \mathrm{C}$ for both species) and heat-shocked (HS; black columns; $30 \pm 2{ }^{\circ} \mathrm{C}$ for $R$. exoculata and $28 \pm 2{ }^{\circ} \mathrm{C}$ for P. varians) specimens. For both species, the expression level of genes was measured $2 \mathrm{~h}$ after the heat-shock and normalized to the corresponding RPL8 abundance. All amplifications were reproduced in triplicate and values correspond to the mean normalized expression $( \pm \mathrm{SEM})$ of at least 3 independent samples ( $n=3$ or 4 individuals). To compare data, Mann-Whitney Test were used and the asterisk indicates a significant difference between the mean normal expression of control and heat-shocked samples $\left({ }^{*} p<0.05\right)$. For each gene, the number above the black columns indicated the fold of induction obtained after heat stress.

expression of $h s p 70$ form 1 was found to significantly increase following the heat-shock (15-fold; Mann-Whitney Test, $p<0.05$ ), whereas no drastic change was observed for hsc70 form2 (1.1-fold; Mann-Whitney Test, $p>0.05$ ) compared to control samples.

\section{Discussion}

\subsection{Characterization of R. exoculata and P. varians HSP70 sequences}

As expected, several general eukaryotic HSP70 family motifs were identified in the amino acid sequences of $R$. exoculata and $P$. varians confirming their belonging to the HSP70 family (see Fig. S1). Several structural characteristics were proposed to differentiate constitutive and inducible isoforms. Some authors have suggested that cytosolic eukaryotic HSC70 has GGMP repeats in the C-terminal region (Prapapanish et al., 1996; Liu et al., 2004; Wu et al., 2008). Both $R$. exoculata hsc70 form3 and $P$. varians hsc70 form2, which, according to our expression analysis encode HSC70 (see below), contain this motif at position 624 (see Fig. S1). However, in R. exoculata hsc70 form3, the tetrapeptide occurs only once (amino acid 624-628), whereas it is repeated twice in P. varians hsc70 form2 (amino acid 624-632). Moreover, such motifs were found in the HSP70 cDNA sequence of the copepod Trigriopus japonicus (four GGMP repeats in the C-terminal region) whereas expression analysis by real-time PCR clearly indicates that this sequence corresponds to a heat-inducible HSP70
(Rhee et al., 2009). Despite the difficulty of identifying a specific motif for HSP70 vs. HSC70 sequences, the nucleotide sequences of the inducible and constitutive forms appeared in separate groups in the phylogenetic tree (Fig. 2). This tree can thus prove useful as a predictive tool for an a priori annotation of hsp70 sequences in decapod crustaceans, especially since the phylogeny obtained is congruent with other phylogeny of Decapoda constructed using nuclear or mitochondrial DNA (Tsang et al., 2008). Nevertheless, gene expression studies after stress exposures still seem to be the only way to unambiguously distinguish $h s p 70$ and $h s c 70$.

\subsection{Thermal characteristics of $P$. varians}

The palaemonid shrimp P. varians is found in very shallow waters and is particularly abundant in areas of salt marsh, where large and acute daily fluctuations of water temperature have been reported (about $10^{\circ} \mathrm{C}$ per $24 \mathrm{~h}$ ) (Nugegoda and Rainbow, 1989; Nielsen and Hagerman, 1998). In addition, this species is known to undergo a wide seasonal gradient of temperature in its environment (from $0{ }^{\circ} \mathrm{C}$ in December to up to $33^{\circ} \mathrm{C}$ in July) (Lofts, 1956; Jefferies, 1964; Healy, 1997). For the specimens used in this study, which were collected during winter, a reference temperature of $10{ }^{\circ} \mathrm{C}$ is assumed to be tolerated by the animals, since first it is close to the water temperature measured at the time of sampling $\left(8^{\circ} \mathrm{C}\right)$ and second it is consistent with the mean temperature suggested to be encountered in the natural habitat of $P$. varians, i.e. $10-15{ }^{\circ} \mathrm{C}$ (Lofts, 1956; Jefferies, 1964). On the contrary, our heat-shock temperature of $28{ }^{\circ} \mathrm{C}$ is close to the environmental maxima reported for P. varians (Lofts, 1956; Healy, 1997) and, in view of the $40 \%$ mortality rate observed at the end of our preliminary heating experiment $\left(35^{\circ} \mathrm{C}\right.$ for $\left.1 \mathrm{~h}\right)$, a $1 \mathrm{~h}$ exposure at $28{ }^{\circ} \mathrm{C}$ may be considered as a severe thermal stress for the animals.

One physiological strategy to cope with thermal stress is the synthesis of heat-shock proteins (HSPs), which prevent protein aggregation and facilitate removal of damaged proteins (Parsell and Lindquist, 1993; Feder and Hofmann, 1999). The expression of HSP70 proteins is thus frequently used as a bioindicator of stress. In this study, we first followed through time the $h s p 70$ expression levels of P. varians after a sudden immersion in a $28{ }^{\circ} \mathrm{C}$-water (Fig. 1A) in order to detect the time of the peak response. Real-time PCR analyses showed a differential regulation of the two $h s p 70$ genes since a rapid increase of inducible $h s p 70$ form 1 ( 15 -fold at $30 \mathrm{~min}, 25$-fold at $2 \mathrm{~h}$ ) with a maximum level at $4 \mathrm{~h}(\sim 54$-fold $)$ was observed, while no significant change was detected for hsc70 form2 (see Fig. 3 ). We thus identified the $h s p 70$ form 1 of $P$. varians as a gene encoding a heatinducible HSP70 protein and the $h s c 70$ form 2 as a gene encoding a HSC70 protein. We can also assume that the exponential phase of the stress response is situated between $30 \mathrm{~min}$ and $4 \mathrm{~h}$ after heat-shock since the induction levels of $h s p 70$ form 1 tends to decrease at $6 \mathrm{~h}$ (43fold). Secondly, we explored the capacity of $P$. varians to respond to a $28^{\circ} \mathrm{C}$ ramp-shock (Fig. 1B) by measuring the levels of $h s p 70$ isoforms through real-time PCR. The results confirmed the differential regulation of the two hsp70 genes since an up-regulation of $h s p 70$ form1 ( 15 -fold) was demonstrated, while no significant change was observed for hsc70 form2 (1.1-fold) (Fig. 3B). Surprisingly, after $2 \mathrm{~h}$ of recovery, we observed an expression level of hsp70 form 1 about 2fold less in the ramp-shock experiment than in the sudden immersion experiment. It thus appears that the heating rate may influence the expression level of inducible $h s p 70$ genes in P. varians. Since the magnitude of HSP synthesis may be proportional to the severity of the heat stress (DiDomenico et al., 1982; Tomanek and Somero, 2000), it seems that, for a $1 \mathrm{~h}$-heat-shock at $28^{\circ} \mathrm{C}$, a rapid heating rate (sudden immersion) induce a higher level of stress than a slow heating rate $\left(0.3^{\circ} \mathrm{C} / \mathrm{s}\right)$ in $P$. varians specimens. This observation appears consistent with the conditions of exposure to heat stress found in the habitat of $P$. varians in which the temporal gradient is principally driven by the tidal rhythm. For an accurate comparison of stress level between 
$P$. varians and $R$. exoculata, the heat-shock experiment in $R$. exoculata was therefore performed with comparable heating rates and the hsp70 expression was detected after $2 \mathrm{~h}$ of recovery (exponential phase of the stress response).

\subsection{Comparison of hsp70 expression between the vent shrimp R. exoculata and the coastal shrimp P. varians}

The reference experiments for $R$. exoculata were performed at in situ pressure $(23 \mathrm{MPa})$, and at a reference temperature of $10^{\circ} \mathrm{C}$, according to our previous work (Ravaux et al., 2003) and to the mean temperature values recorded in the shrimp microenvironment, 10$15^{\circ} \mathrm{C}$ (Segonzac et al., 1993; Desbruyères et al., 2001; Schmidt et al., 2008). We can therefore assume that, with a $92 \%$ survival rate with no drastic change in general behaviour, our reference conditions are tolerated by the animals. On the contrary, and in view of the thermal resistance of $R$. exoculata $\left(33-38.5 \pm 2{ }^{\circ} \mathrm{C}\right.$ ) (Ravaux et al., 2003; Shillito et al., 2006), our heat-shock experiment ( $30^{\circ} \mathrm{C}$-exposure for $1 \mathrm{~h}$ ) may be considered as sufficient to induce stress in the shrimps.

Both hydrothermal and coastal species live in highly fluctuating environments where temperature can regularly approach their lethal limits (Gebruk et al., 1993; Shillito et al., 2006; Helmuth and Hofmann, 2001; and the present work). One of the objectives of this study was to compare the stress response of the hydrothermal vent shrimp with a related coastal species following a similar severe thermal stress in order to characterize the adaptation mechanisms of $R$. exoculata regarding hyperthermia. For a relative comparison between species, quantification of $h s p 70$ genes expression was performed using real-time PCR, which is currently the most sensitive method to quantify gene expression (Bustin, 2000). Furthermore, total RNAs were extracted from the same tissues (abdomen muscles) in both shrimps, since the expression of HSP70 is known to be tissuespecific (Wang et al., 2007; Wu et al., 2008). The results for $R$. exoculata show a dramatic increase of $h s p 70$ form 1 (373-fold) and hsp70 form2 (132-fold) expression levels following a $30^{\circ} \mathrm{C}$-exposure whereas the expression of $h s c 70$ form3 (1.9-fold) and $h s c 70$ form 4 (0.7-fold) were not significantly affected (Fig. 4A). This shows that $h s p 70$ form 1 and $h s p 70$ form2 encode heat-inducible forms while hsc70 form 3 and hsc70 form 4 are coding for constitutive forms. Thus, for comparable heat stress conditions, the shrimp $R$. exoculata displays, for at least two genes, considerably higher levels of inducible HSP70 mRNA than the coastal shrimp. In fact, when compared to the expression of $P$. varians $h s p 70$ form1, the expression of $R$. exoculata $h s p 70$ form 1 is 25 -fold higher and the expression of R. exoculata hsp70 form2 is 9-fold higher. Since induction of HSP70 proteins is essential to reduce the damaging effects of heat stress (Feder and Hofmann, 1999; Parsell and Lindquist, 1993; Sørensen et al., 2003), the highly inducible molecular response observed in $R$. exoculata may contribute to the ability of this species to tolerate extreme temperature, while the lower inducibility in $P$. varians suggests that either it is more susceptible to cellular damages, or bears other defence mechanisms with respect to hyperthermia. The combined protection of the two inducible $h s p 70$ genes in $R$. exoculata may also help this shrimp cope with the stressful thermal conditions of hydrothermal vent habitats.

To our knowledge, studies that have measured hsp70 mRNA after thermal stress in marine species by real-time PCR report levels of induction ranging from less than 10-fold (Voznesensky et al., 2004; Cellura et al., 2006; Park et al., 2007; Rhee et al., 2009) to thousandfolds (Ojima et al., 2005a; Osovitz and Hofmann, 2005; Clark et al., 2008). The levels of hsp70 mRNA detected for $R$. exoculata are comparable with those of a cold-water fish, the rainbow trout Oncorhynchus mykiss (480-fold after a 3 h-heat-shock at $28^{\circ} \mathrm{C}$; Ojima et al., 2005a), for which a 50\% mortality rate was shown after 1 week at $26{ }^{\circ} \mathrm{C}$ (Ojima et al., 2005b). Moreover, it is also in the same range of another cold-water species, the purple sea urchin Strongylocentrotus purpuratus ( 250 -fold after a 30 min-heat-shock at $26^{\circ} \mathrm{C}$ ), known to routinely experience temperature near $4{ }^{\circ} \mathrm{C}$ in its natural habitat (Osovitz and Hofmann, 2005). Finally, hsp70 genes expression levels higher than $R$. exoculata were reported in the Antarctic marine mollusc, Nacella concinna (almost 2000-fold after a 2 h-heat-shock at $\left.20{ }^{\circ} \mathrm{C}\right)$, which used to live at low $\left(-1.86\right.$ to $\left.+1{ }^{\circ} \mathrm{C}\right)$ and stable seawater temperatures (Clark et al., 2008). On the contrary, the level measured for $P$. varians $h s p 70$ form 1 is similar to that of the mussel Mytilus galloprovincialis (6-fold induction after a 90 min-heat-shock at $30^{\circ} \mathrm{C}$; Cellura et al., 2006) or the abalone Haliotis tuberculata (4-fold after a 1 h-heat-shock at $37^{\circ} \mathrm{C}$; Farcy et al., 2007), two other thermally-challenged species. It thus appears that, as opposed to $P$. varians, the level expression obtained in $R$. exoculata is comparable to species that rarely undergo heat stress in their habitat. Moreover, low levels of $h s p 70$ gene have been recently reported in natural populations of $R$. exoculata (Ravaux et al., 2009). From these results, we can suggest that $R$. exoculata rarely encounters sustained temperature close to its thermal limits in situ. This mobile species may therefore avoid prolonged contacts with high temperature zones through a behavioural response, while a strong molecular response may be triggered in case of occasional and unpredictable thermal extremes. Further studies are needed to support this hypothesis. For example, additional experiments will be necessary to determine the existence of an exposure duration threshold (a few minutes) at elevated temperature $\left(30^{\circ} \mathrm{C}\right.$ and more), which would result in lower expression of inducible $h s p 70$ genes in $R$. exoculata. Moreover, the optimal temperature necessary for an efficient carbon fixation by the epibionts has to be specified in order to understand better the thermoregulatory behaviour of this shrimp.

\section{Acknowledgements}

We wish to thank the captain and crew of the R/V Pourquoi pas?, the crew of the Nautile submersible, and the chief scientists of the Momardream cruise, Françoise Gaill and Jérôme Dyment. We are grateful to Magali Zbinden and Jean-Yves Toullec for their help in experimental work on board. We also wish to thank Philippe Lopez for his help in sequence analysis. We acknowledge funding support from the GDR Ecchis and the European Community program EXOCET/D. This work was supported by the Marine Biodiversity and Ecosystem Functioning Network of Excellence MarBEF (contract no. GOCE-CT2003-505446) of the FP6, and a research grant from the Total Foundation (“Abyss2100"). [SS]

\section{Appendix A. Supplementary data}

Supplementary data associated with this article can be found, in the online version, at doi:10.1016/j.jembe.2010.06.008.

\section{References}

Bustin, S.A., 2000. Absolute quantification of mRNA using real-time reverse transcription polymerase chain reaction assays. J. Mol. Endocrinol. 25, 169-193.

Boutet, I., Tanguy, A., Le Guen, D., Piccino, P., Hourdez, S., Legendre, P., Jollivet, D., 2009. Global depression in gene expression as a response to rapid thermal changes in vent mussels. Proc. R. Soc. B 276, 3071-3079.

Cellura, C., Toubiana, M., Parrinello, N., Roch, P., 2006. Hsp70 gene expression in Mytilus galloprovincialis hemocytes is triggered by moderate heat-shock and Vibrio anguillarum, but not by V. splendidus or Micrococcus lysodeikticus. Dev. Comp. Immunol. 30, 984-997.

Childress, J.J., Fisher, C.R., 1992. The biology of hydrothermal vent animals: physiology, biochemistry, and autotrophic symbioses. Oceanogr. Mar. Biol. Ann. Rev. 30, 337-441.

Clark, M.S., Fraser, K.P.P., Peck, L.S., 2008. Antartic marine molluscs do have an HSP70 heat shock response. Cell Stress Chaperones 13, 39-49.

Cottin, D., Ravaux, J., Léger, N., Halary, S., Toullec, J.Y., Sarradin, P.M., Gaill, F., Shillito, B., 2008. Thermal biology of the deep-sea vent annelid Paralvinella grasslei: in vivo studies. J. Exp. Biol. 211, 2196-2204.

Desbruyères, D., Almeida, A., Biscoito, M., Comtet, T., Khripounoff, A., Le Bris, N., Sarradin, P.M., Segonzac, M., 2000. A review of the distribution of hydrothermal vent communities along the Northern Mid-Atlantic Ridge: dispersal vs environmental controls. Hydrobiology 440, 201-216. 
Desbruyères, D., Biscoito, M., Caprais, J.C., Colaço, A., Comtet, T., Crassous, P., Fouquet, Y. Khripounoff, A., Le Bris, N., Olu, K., Riso, R., Sarradin, P.M., Segonzac, M., Vangriesheim, A., 2001. Variations in the deep-sea hydrothermal vent communities on the Mid-Atlantic Ridge near the Azores plateau. Deep-Sea Res. 48, 1325-1346.

DiDomenico, B.J., Bugaisky, G.E., Lindquist, S., 1982. Heat shock and recovery are mediated by different translational mechanisms. Proc. Natl Acad. Sci. USA 79 6181-6185.

Farcy, E., Serpentini, A., Fiévet, B., Lebel, J.M., 2007. Identification of cDNAs encoding HSP70 and HSP90 in the abalone Haliotis tuberculata: transcriptional induction in response to thermal stress in hemocyte primary culture. Comp. Biochem. Physiol. B $146,540-550$.

Feder, M.E., Hofmann, G.E., 1999. Heat-shock proteins, molecular chaperones, and the stress response: evolutionary and ecological physiology. Annu. Rev. Physiol. 61 243-282.

Fisher, C.R., 1998. Temperature and sulfide tolerance of hydrothermal vent fauna. Cah. Biol. Mar. 39, 283-286.

Gebruk, A.V., Pimenov, N.V., Savvichev, A.S., 1993. Feeding specialization of bresiliid shrimps in the TAG site hydrothermal community. Mar. Ecol. Prog. Ser. 98 247-253.

Gebruk, A.V., Southward, E.C., Kennedy, H., Southward, A.J., 2000. Food source, behaviour and distribution of hydrothermal vent shrimps at the Mid-Atlantic Ridge. J. Mar. Biol. Assoc. UK 80, 485-499.

Guindon, S., Gascuel, O., 2003. A simple, fast, and accurate algorithm to estimate large phylogenies by maximum likelihood. Syst. Biol. 52 (5), 696-704.

Healy, B., 1997. Long-term changes in a brackish lagoon, Lady's Island lake, South-east Ireland. Biology and Environment. Proc. R. Ir. Acad. 97B, 33-51.

Helmuth, B.S.T., Hofmann, G.E., 2001. Microhabitats, thermal heterogeneity, and patterns of physiological stress in the rocky intertidal zone. Biol. Bull. 201, 374-384.

Jefferies, D.J., 1964. The moulting behaviour of Palaemonetes varians (Leach) (Decapoda; Palemonidae). Hydrobiology 24, 457-488.

Leignel, V., Cibois, M., Moreau, B., Chénais, B., 2007. Identification of new subgroup of HSP70 in Bythograeidae (hydrothermal crabs) and Xanthidae. Gene 396, 84-92.

Lindquist, S., Craig, E.A., 1988. The heat-shock proteins. Annu. Rev. Genet. 22, 631-677.

Liu, J. Yang WJ. Zhu, XJ. Karouna-Reinier, N.K. Rao, R.K, 2004. Molecular cloning and expression of two hsp70 genes in the prawn, Macrobrachium rosenbergii. Cell Stress Chaperones 9, 313-323.

Lofts, B., 1956. The effects of salinity changes on the respiratory rate of the prawn Palaemonetes varians (Leach). J. Exp. Biol. 33, 730-736.

Mayer, M.P., Bukau, B., 2005. Hsp70 chaperones: cellular functions and molecular mechanism. Cell. Mol. Life Sci. 62, 670-684.

Mestre, N., Thatje, S., Tyler, P.A., 2009. The ocean is not deep enough: pressure tolerances during early ontogeny of the blue mussel Mytilus edulis. Proc. R. Soc. B 276, 717-726.

Nielsen, A., Hagerman, L., 1998. Effects of short-term hypoxia on metabolism and haemocyanin oxygen transport in the prawns Palaemonetes adspersus and Palaemonetes varians. Mar. Ecol. Prog. Ser. 167, 177-183.

Nugegoda, D., Rainbow, P.S., 1989. Effects of salinity changes on zinc uptake and regulation by the decapod crustaceans Palaemonetes elegans and Palaemonetes varians. Mar. Ecol. Prog. Ser. 51, 57-75.

Ojima, N., Yamashita, M., Watabe, S., 2005a. Quantitative mRNA expression profiling of heat-shock protein families in rainbow trout cells. Biochem. Biophys. Res. Commun. 329, 51-57.

Ojima, N., Yamashita, M., Watabe, S., 2005b. Comparative expression analysis of two paralogous Hsp70s in rainbown trout cells exposed to heat stress. Biochem. Biophys. Acta 1681, 99-106.

Osovitz, C.J., Hofmann, G.E., 2005. Thermal history-dependent expression of the $h s p 70$ gene in purple sea urchins: biogeographic patterns and the effect of temperature acclimation. J. Exp. Mar. Biol. Ecol. 327, 134-143.

Park, H., Ahn, I.Y., Lee, H.E., 2007. Expression of heat shock protein 70 in the thermally stressed Antartic clam Laternula elliptica. Cell Stress Chaperones 12, 275-282.

Parsell, D.A., Lindquist, S., 1993. The function of heat-shock proteins in stress tolerance: degradation and reactivation of damaged proteins. Annu. Rev. Genet. 27, 437-496.
Prapapanish, V., Chen, S., Toran, E.J., Rimerman, R.A., Smith, D.F., 1996. Mutational analysis of the hsp70-interacting protein Hip. Mol. Cell. Biol. 16, 6200-6207.

Pruski, A.M., Dixon, D.R., 2007. Heat shock protein expression pattern (HSP70) in the hydrothermal vent mussel Bathymodiolus azoricus. Mar. Environ. Res. 64, 209-224.

Ravaux, J., Gaill, F., Le Bris, N., Sarradin, P.M., Jollivet, D., Shillito, B., 2003. Heat shock response and temperature resistance in the deep-sea vent shrimp Rimicaris exoculata. J. Exp. Biol. 206, 2345-2354

Ravaux, J., Toullec, J.Y., Léger, N., Lopez, P., Gaill, F., Shillito, B., 2007. First hsp70 from two hydrothermal vent shrimps, Mirocaris fortunata and Rimicaris exoculta: characterization and sequence analysis. Gene 386, 162-172.

Ravaux, J., Cottin, D., Chertemps, T., Hamel, G., Shillito, B., 2009. Hydrothermal shrimps display low expression of heat-inducible $h s p 70$ gene in nature. Mar. Ecol. Prog. Ser. 396, 153-156.

Rieley, G., Van Dover, C.L., Hedrick, D.B., Eglintin, G., 1999. Trophic ecology of Rimicaris exoculata: a combined lipid abundance/stable isotope approach. Mar. Biol. 133 495-499.

Rhee, J.S., Raisuddin, S., Lee, K.W., Seo, J.S., Ki, J.S., Kim, I.C., 2009. Heat shock protein (Hsp) gene responses of the intertidal copepod Tigriopus japonicus to environmental toxicants. Comp. Biochem. Physiol. C 149, 104-112.

Sanders, B.M., 1993. Stress proteins in aquatic organisms: an environmental perspective. Crit. Rev. Toxicol. 23, 49-75.

Schmidt, C., Le Bris, N., Gaill, F., 2008. Interactions of deep-sea vent invertebrates with their environment: the case of Rimicaris exoculata. J. Shell. Res. 27 (1), 9-90.

Segonzac, M., De Saint Laurent, M., Casanova, B., 1993. L'énigme du comportement trophique des crevettes Alvinocarididea des sites hydrothermaux de la dorsale médio-atlantique. Cah. Biol. Mar. 34, 535-571.

Shillito, B., Le Bris, N., Hourdez, S., Ravaux, J., Cottin, D., Caprais, J.C., Jollivet, D., Gaill, F., 2006. Temperature resistance studies on the deep-sea vent shrimp Mirocaris fortunata. J. Exp. Biol. 209, 945-955.

Somero, G.N., 1992. Biochemical ecology of deep-sea animals. Experiencia 48, 537-543.

Sørensen, J.G., Kristensen, T.N., Loeschcke, V., 2003. The evolutionary and ecological role of heat shock proteins. Ecol. Lett. 6, 1025-1037.

Tokuda, G., Yamada, A., Nakano, K., Arita, N., Yamasaki, H., 2006. Occurrence and recen long-distance dispersal of deep-sea hydrothermal vent shrimps. Biol. Lett. 2, 257-260.

Tomanek, L., Somero, G.N., 2000. Time course and magnitude of synthesis of heat-shock proteins in congeneric marine snails (Genus Tegula) from different tidal heights. Physiol. Biochem. Zool. 73, 249-256.

Tsang, L.M., Ma, K.Y., Ahyong, S.T., Chan, T.Y., Chu, K.H., 2008. Phylogeny of Decapoda using two nuclear protein-coding genes: origin and evolution of the Reptantia. Mol. Phylogenet. Evol. 48, 359-368.

Tunnicliffe, V., 1991. Hydrothermal vent biology: ecology and evolution. Oceanogr. Mar Biol. Annu. Rev. 29, 319-407.

Van Dover, C.L., Fry, B., Grassle, J.F., Humphris, S., Rona, P.A., 1988. Feeding biology of the shrimp Rimicaris exoculata at hydrothermal vents on the Mid-Atlantic Ridge. Mar. Biol. 98, 209-216.

Voznesensky, M., Lenz, P., Spanings-Pierrot, C., Towle, D., 2004. Genomic approaches to detecting thermal stress in Calanus finmarchicus (Copepoda: Calanoida). J. Exp. Mar. Biol. Ecol. 311, 37-46.

Wang, Y., Xu, J., Sheng, L., Zheng, Y., 2007. Field and laboratory investigations of the thermal influence on tissue-specific Hsp70 levels in common carp (Cyprinus carpio). Comp. Biochem. Physiol. A 148, 821-827.

Williams, A.B., Rona, P.A., 1986. Two new Caridean shrimps (Bresillidae) from a hydrothermal field on the Mid-Atlantic Ridge. J. Crust. Biol. 6, 446-462.

Wirsen, C.O., Jannasch, H.W., Molyneaux, S.J., 1993. Chemosynthetic microbial activity at Mid-Atlantic Ridge hydrothermal vent sites. J. Geophys. Res. 98, 9693-9703.

Wu, R., Sun, Y., Lei, L.M., Xie, S.T., 2008. Molecular identification and expression of hea shock cognate (HSC70) in the pacific white shrimp Litopenaeus vannamei. Mol. Biol. 42 (2), 265-274

Zbinden, M., Le Bris, N., Gaill, F., Compère, P., 2004. Distribution of bacteria and associated minerals in the gill chamber of the vent shrimp Rimicaris exoculata and related biogeochemical processes. Mar. Ecol. Prog. Ser. 284, 237-251. 